\title{
"Self-managed", inadequate "adherence" to antiretroviral therapy, limited to one half of standard dosages, followed by an unexpected, sustained virological and immunological success
}

Roberto Manfredi

From $16^{\text {th }}$ International Symposium on HIV and Emerging Infectious Diseases

Marseille, France. 24-26 March 2010

\section{Background}

Antiretroviral adherence issues are essential for successful and sustained efficacy, and viral resistance prevention.

\section{Methods}

One exceptional case regards an ex-IVDA patient (p) with HIV infection known since 1985. Due to a severe HIV-related immunosuppression (CD4: 37 cells/ $\mu \mathrm{L}$ ), in 1997 3TC, d4T, and indinavir was effectively started, achieving after 3 months undetectable viremia and a CD4 count of 315 cells $/ \mu \mathrm{L}$, but recurring urolithiasis recommended a therapeutic shift. Since April 1997,3TC, $\mathrm{d} 4 \mathrm{~T}$, and ritonavir were suggested for 5 years, followed by $3 \mathrm{TC}, \mathrm{d} 4 \mathrm{~T}$, and lopinavir-ritonavir (10 months), and 3TC, AZT, and lopinavir-ritonavir (6 years). However, all proposed regimens were voluntarily taken by our $\mathrm{p}$ (whose body weight was $75-80 \mathrm{Kg}$ ) at half-dose, as a single daily dosage, against any recommendation, although our p always maintained his "adherence" to his selfmade regimen, as assessed by monthly visits, direct drug distribution-accountabilty, and adherence questionnaires. Surprisingly, viremia remained for 12 years at non-detectable values (save one single detection of 1,260 HIV-RNA copies $/ \mu \mathrm{L}$ ), so that a genotypic resistance testing was never feasible, while CD4 count ranged from a nadir of 382 cells $/ \mu \mathrm{L}$ (year 2001), to $525-794$ cells $/ \mu \mathrm{L}$ since 2003.

\section{Results}

A second male p with a body weight of $69-73 \mathrm{Kg}$, since 2002 took all combined antiretroviral therapy at half dosage (3TC $150 \mathrm{mg} /$ day, AZT $300 \mathrm{mg} /$ day, and lopinavir-ritonavir $2 \mathrm{cp} /$ day for 7 years, as a single daily dose), without showing detectable viremias, and CD4 counts $>500$ cells $/ \mu \mathrm{L}$. A third 48 -y-old male, after two changes of antiretroviral regimens due to dysmetabolism, started the fixed dose AZT-3TC-abacavir combination at half dosage (one pill/day), and since 2003 had a persistingly negative viremia, and a CD4 count always $>650$ cells $/ \mu \mathrm{L}$. In both these last $2 \mathrm{p}$, genotypic resistance testing was not feasible (undetectable viremia).

\section{Discussion}

Although recognizing the limitation of anecdotal observations, and our impossibility to resort to resistance testing and therapeutic drug monitoring, however the long-term maintenance of an excellent virologic-immunological situation in $3 \mathrm{p}$ with an adherence voluntarily limited to $50 \%$ of recommended dosages depite all counselling, deserves discussion. A 50\% compliance is considered absolutely inadequate in HIV disease treatment. Anyway, all our $3 \mathrm{p}$ are somewhat "adherent" to their $50 \%$ dosage regimens, and are re-enforced in their wrong consideration by checking every 3 months their excellent clinical-laboratory situation, and by their long-

Correspondence: Roberto.manfredi@unibo.it

Infectious Diseases, University of Bologna, S. Orsola Hospital, Bologna, Italy 
term, unchanged therapy response. Health care professionals are embarrassed in discussing this inappropriate mode of antiretroviral seld-administration, but lack of supporting elements to opposite to the strongloy radicated p's thoughts.

Published: 11 May 2010

doi:10.1186/1742-4690-7-S1-P60

Cite this article as: Manfredi: "Self-managed", inadequate "adherence"

to antiretroviral therapy, limited to one half of standard dosages,

followed by an unexpected, sustained virological and immunological

success. Retrovirology 2010 7(Suppl 1):P60.

Submit your next manuscript to BioMed Central and take full advantage of:

- Convenient online submission

- Thorough peer review

- No space constraints or color figure charges

- Immediate publication on acceptance

- Inclusion in PubMed, CAS, Scopus and Google Scholar

- Research which is freely available for redistribution

Submit your manuscript at www.biomedcentral.com/submit 